\title{
The Importance of Instilling an Entrepreneurial Soul in Primary School Age Children in The Face of The Digital Era
}

\section{Frizky Rahmadhani, Anisatun Chasanah, Lin Wahyuni}

Universitas Sebelas Maret

frizkyrahmadhani@gmail.com

\section{Article History}

accepted 24/09/2019

approved 01/10/2019

published 01/12/2019

\begin{abstract}
Entrepreneurship is an ability in terms of creating business activities as contained in Law no. 20 of 2003 concerning the National Education System, that education is expected to be able to achieve the formation of cognitive (intellectual) aspects of affective (mental or moral) and psychomotor (skill) aspects. To instill an entrepreneurial spirit in elementary school age children, it is better to use concrete or concrete examples that are in accordance with Piaget's opinion that children at the age of 7-12 years enter the concrete operational stage, where children will easily understand material or knowledge if children are confronted with something or real conditions. When children enter education in elementary schools, entrepreneurship is used to prepare for the economic challenges of the Industrial Revolution era, which requires that future generations can keep up with the times, especially in terms of digital technology.
\end{abstract}

Keywords: Entrepreneurship, Elementary School Age Children, Digital Era

\begin{abstract}
Abstrak
Kewirausahaan merupakan suatu kemampuan dalam hal menciptakan kegiatan usaha seperti yang terdapat dalam UU No. 20 tahun 2003 tentang Sistem Pendidikan Nasional, bahwa dari pendidikan diharapkan mampu mencapai terbentuknya aspek kognitif (intelektual) aspek afektif (mental atau moral) serta psikomotor (keterampilan). Untuk menanamkan jiwa kewirausahaan pada anak usia Sekolah Dasar lebih baik menggunakan contoh konkrit atau nyata yang sesuai dengan pendapat dari Piaget yaitu anak pada usia 7-12 tahun masuk pada tahap operasional konkrit, dimana anak akan mudah memahami materi atau pengetahuan apabila anak dihadapkan pada sesuatu atau kondisi yang nyata. Pada saat anak memasuki pendidikan di Sekolah Dasar kewirausahaan dijadikan bekal untuk menghadapi tantangan ekonomi di era Revolusi Industri yang mengharuskan generasi penerus dapat mengikuti perkembangan zaman terutama dalam hal teknologi digital.
\end{abstract}

Kata kunci: Kewirausahaan, Anak Usia Sekolah Dasar, Era Digital

Social, Humanities, and Education Studies (SHEs): Conference Series https://jurnal.uns.ac.id/shes

p-ISSN 2620-9284

e-ISSN 2620-9292 


\section{PENDAHULUAN}

Indonesia merupakan negara yang memiliki jumlah penduduk yang sangat banyak serta memiliki sumber kekayaan alam yang melimpah, ini membuat Indonesia pantas disebut sebagai negara yang kaya akan sumber dayanya, baik pada sumber daya alam maupun sumber daya manusianya. Hal ini harusnya dapat memberikan keuntungan besar untuk perekonomian di Indonesia. Namun hal itu belum bisa terwujud karena keadaan di Indonesia sekarang tidak seperti yang kita bayangkan. Ini karena pemerintah Indonesia yang belum dapat mengefesiensikan sumber daya alam dan manusianya yang melimpah. Menurut data worldometers, pada tahun 2017 jumlah penduduk Indonesai mencapai 264.650 .963 jiwa, sedangkan pada tahun 2018 sejumlah 267.670.543 jiwa. Sedangkan berdasarkan Kementrian Kesehatan RI menyebutkan pada tahun 2018, jumlah usia produktif (usia 15-64 tahun) berjumlah 179.126.971 jiwa yang terbagi atas 90.005.335 jiwa laki-laki dan 89.121.636 jiwa perempuan. Faktanya sekarang, banyak warga Indonesia yang tidak memiliki pekerjaan atau dengan kata lain menjadi pengangguran di negaranya sendiri. Semakin tingginya tingkat kelahiran warga Indonesia namun tidak dibarengi dengan banyaknya lapangan kerja yang tersedia, membuat jumlah pengangguran di Indonesia menjadi semakin tinggi.

Banyaknya jumlah penduduk di Indonesia dan terbatasnya lapangan kerja yang memadai membuat masalah pengangguran di Indonesia menjadi masalah yang sulit untuk diatasi oleh pemerintah. Lambatnya penanganan pemerintah dalam menyikapi masalah ini, membuat perekonomian Indonesia semakin terpuruk. Sebenarnya banyak yang bisa dilakukan oleh pemerintah untuk mengatasi masalah pengangguran di Indonesia, salah satunya adalah membuka lebih banyak lapangan pekerjaan untuk warganya. Jika pemerintah dapat bergerak cepat, tidak mustahil masalah pengangguran yang ada di Indonesia ini akan teratasi.

Berdasarkan data worldometers per 27 Januari 2019, jumlah penduduk Indonesia tahun 2019 sebanyak 269.536.482 jiwa. Indonesia berada di peringkat 4 (empat) sebagai negara dengan jumlah penduduk terbanyak di dunia. Namun, besarnya kuantitas penduduk di Indonesia ini belum dibarengi oleh aspek kualitas manusianya apabila dibandingkan dengan negara-negara yang lain, kualitas manusia Indonesia masih termasuk rendah. Berdasarkan data Biro Pusat Statistik (BPS) pada Februari 2019, jumlah pengangguran di Indonesia mencapai 6,82 juta orang. Pada tahun 2016 Tingkat Pengangguran Terbuka (TPT) di perkotaan sebesar 6,53\% sedangkan di pedesaan sebesar 4,53\%. Pada tahun 2017 TPT tercatat 5,33\% dengan rincian TPT perkotaan sebesar $6,50 \%$ dan pedesaan sebesar $4 \%$. Sementara pada tahun 2019 Tingkat Pengangguran Terbuka (TPT) sebesar 5,13\%. TPT di perkotaan sebesar $6,34 \%$ sementara di pedesaan sebesar 3,72\%. Dari data tersebut, walaupun tingkat pengangguran mengalami penurunan kondisi pertumbuhan ekonomi belum mampu mendorong penyerapan tenaga kerja yang tersedia. Masalah sumber daya manusia Indonesia tersebut dinilai sangat kompleks karena tidak hanya tingkat pendidikan yang rendah, namun lulusan SMK maupun perguruan tinggi yang seharusnya sudah matang pekerja, ternyata belum siap pakai.

Kejadian dilapangan menunjukkan bahwa banyak angkatan kerja yang ada belum terserap dengan maksimal pada sektor ekonomi formal. Sementara, untuk masuk sektor non-formal, masyarakat belum memiliki bekal keterampilan yang memadai untuk menciptakan usaha bidang ekonomi kreatif. Hal tersebut merupakan masalah besar yang harus dihadapi bangsa Indonesia saat ini dan masih harus dihadapi pada masa yang akan datang. Problematika tersebut harus segera dihadapi dengan mencari jalan keluar salah satunya yaitu menanamkan jiwa kewirausahaan sejak memasuki usia Sekolah Dasar untuk memberikan bekal dasar agar mampu 
menghadapi tantangan ekonomi dimasa yang akan datang yang menuntut kemahiran dalam penggunaan teknologi.

Menurut (Kasmir,2011) Kewirausahaan adalah suatu proses penerapan kreatifitas dalam memecahkan persoalan dan menemukan peluang untuk memperbaiki kehidupan. Yang merupakan suatu kemampuan dalam hal menciptakan kegiatan usaha seperti dalam UU No. 20 tahun 2003 tentang Sistem Pendidikan Nasional, bahwa dari pendidikan diharapkan mampu mencapai terbentuknya aspek kognitif (intelektual) aspek afektif (mental atau moral) serta psikomotor (keterampilan). dalam karakter jiwa kewirausahaan yang menjadi pengembangannya yaitu keterampilan dan aspek mental yang dimiliki siswa sejak dini. Dengan adanya pembiasaan sejak dini diharapkan keterampilan dan mental peserta didik semakin matang untuk dapat berwirausaha. Dalam UU No. 20 tahun 2003 tersebut juga mengemukakan bahwa pendidikan nasional berfungsi untuk mengembangkan kemampuan dan membentukkarakter dan juga manusia yang bermartabat dalam mencerdaskan kehidupan bangsa yang bertujuan untuk mengembangkan potensi yang dimiliki peserta didik sehingga menjadi manusia yang beriman dan bertaqwa kepada Tuhan Yang Maha Esa, berakhlak mulia, sehat, bertanggungjawab, kreatif. Dengancara membiasakan keterampilan dalam berwirausaha maka potensi peserta didik dapat menjadi nyata seperti yang terdapat dalam UUD sisdiknas tersebut.Menurut Saroni (2013), dengan memberikan kompetensi kewirausahaan seperti kegiatan produktif kepada peserta didik dapat menjadikansosok efektif dalam kehidupan. Jika peserta didik mempunyai keterampilan dalam berwirausaha maka dapat menjadi pribadi yang lebih bertanggungjawab atas kehidupannya.

\section{METODE}

Dalam penulisan ini, penulis memanfaatkan jenis penelitian yaitu studi kepustakaan (library research),yang merupakan sekumpulan kegiatan yang berkaitan dengan metode pengumpulan data pustaka. Menurut Sugiyono (2012: 291), studi pustaka berhubungan dengan kajian teori dan referensi-referensi yang berkaitan dengan nilai-nilai, norma-norma yang berkembang pada masyarakat sosial yang diteliti, selain itu studi pustaka sangat penting dalam melakukan penelitian tidak akan lepas dari literatur-literatur ilmiah. Dalam penulisan ini penulis memperoleh literatur dari berbagai sumber yaitu buku-buku, jurnal, dan internet untuk mengetahui pentingnya menanamkan jiwa kewirausahaan pada anak usia Sekolah Dasar dalam menghadapi era digital.

\section{HASIL DAN PEMBAHASAN Kondisi wirausaha di Indonesia dan penggunaan teknologi}

Wilayah Indonesia mempunyai potensi yang baik dalam menumbuhkemembangkan wirausahawan baru. Data statitik menyatakan bahwa pada tahun 2030, Indonesia diperkirakan mempunyai penduduk yang berusia produktif sebanyak $60 \%$, dengan $30 \%$-nya yaitu penduduk usia muda dengan potensi menjadi seorang wirausaha. Pola kehidupan yang saat ini berkembang sangat mendukung dan memberikan kemudahan dala mengakses produk-produk usaha, seperti usaha mikro kecil dan menengah (UMKM) dan juga koperasi-koperasi yang terdapat di sekolahsekolah dasar.

Indikator tingkat kemajuan suatu negara dapat ditentukan dengan banyaknya jumlah wirausaha yang berada di negara tersebut.Dilansir dari Koran Jakarta (8/1/2018) Jumlah wirausaha di Tanah Air telah tembus $3,1 \%$ dari total jumlah penduduk yang pada tahun 2017 sekitar 260 juta jiwa. Angka tersebut telah melampaui standar internasional sebanyak $2 \%$. Pada tahun sebelumnya 2016, rasio wirausaha di 
Tanah Air baru 1,65 \%, hingga akhir tahun 2017 telah mencapai lebih dari 3,1\%. Meskipun demikian jumlah wirausaha di Indonesia masih terbilang cukup rendah dibandingkan dengan Malaysia yang telah mencapai 5\% dan Singapura 7\% serta negara Amerika dengan $12 \%$ penduduknya adalah menjadi wirausaha. Sayangnya hingga saat ini, jumlah orang yang menjadi pengusaha (wirausaha) di Indonesia minatnya masih sedikit dan mutu yang dihasilkan oleh wirausaha tersebut juga belum bisa dikatakan memiliki mutu yang tinggi hingga dikatakan hebat untuk menopang suatu perekonomian, sehingga adanya suatu persoalan wirausaha ini menjadi masalah serius dan tidak main-main bagi sukses serta lancarnya roda pembangunan dunia untuk perekonomian bangsa Indonesia dan harus segera ditangani agar tidak tertinggal dari negara-negara lain.

Dengan kondisi yang seperti itu di Indonesia sangat diperlukan peningkatan kulaitas sumber daya manusia yang harus mulai diajarkan oleh anak-anak usia Sekolah Dasar yang sudah mempunyai pikiran yang berkembang khususnya anak Sekolah Dasar kelas tinggi.

\section{Angka Melek Teknologi Digital}

Menurut APJII sebuah Asosiasi Penyelenggara Jasa Internet Indonesia) pengguna internet di Indonesia telah mengalami sebuah peningkatan pada tahun sebelumnya yaitu 2018. Jumlah populasi pada tahun tersebut sebanyak 267.670 .543 jiwa ada sebanyak 171,17 juta jiwa atau sekitar $64,8 \%$ orang sudah melek akan teknologi internet. Angka tersebut mengalami peeningkatan daripada tahun 2017 yang hanya mencapai $54,86 \%$.

Dalam era teknologi internet yang semakin berkembang dibutuhkan peran guru serta orang tua untuk mengawasi akses internet pada anak. Sebagai guru harus mampu membimbing anak di Sekolah agar mampu mengoperasikan komputer dan internet dengan baik. Peran orang tua saat di rumah harus mampu membimbing anakanak agar mampu memilah dan memilih akses internet yang baik dan memiliki nilai edukasi bagi anak, jangan sampai anak hanya menggunakan internet untuk bermainmain yang tidak memiliki nilai edukasi misalnya game online, menonton tayangan yang tidak sesuai dengan tingkatan usia, dan hal-hal yang tidak sepantasnya mereka akses dan dapat membahayakan masa depan mereka.

\section{Menanamkan Jiwa Kewirausahaan Pada Anak Sekolah Dasar}

Pendidikan Kewirausahaan merupakan salah satu pendidikan yang mampu memberi bekal keterampilan untuk siswa dalam menghadapi masa yang akan datang. Saat ini Pemerintah mulai menggalakkan pendidikan kewirausahaan di perguruan tinggi untuk mahasiswa melalui kegiatan Pekan Kreativitas Mahasiswa (PKM), tetapi alangkah lebih baiknya jika pendidikan kewirausahaan tersebut dimulai dari pendidikan dasar yaitu Sekolah Dasar agar anak-anak mempunyai bekal keterampilan berwirausaha sejak dini yang tentu saja berguna untuk pengembangan keterampilan dasar mereka ke arah yang lebih baik.

Karakteristik seorang wirausaha yang biasa dijuluki dengan seorang entrepreneur yang dikemukakanzolehzDaryanto (2012: 32-25) antara lain pekerja keras juga cerdas, individu yang percaya diri, membangun untuk masa depan, berorientasi pada perolehan laba, berorientasi pada sasaran, teguh, dapat mengatasi kegagalan, kemampuan memberikan umpan balik atau respon, menunjukkan inisiatif, menjadi pendengar yang baik, menetapkan standar kinerja diri sendiri.

Karakter anak sudah dibangun dari apa yang anak dengarkan, melihat dan apa yang mereka rasakan. Sebagai guru yang baik harus memberikan suri teladan juga 
arahan serta bimbingan yang disesuaikan karakteristik masing-masing anak, khususnya saat anak memasuki usia SD. Pendidikan anak di jenjang SD merupakan pendidikan formal awal paling lama waktunya yaitu 6 tahun dibandingkan dengan jenjang pendidikan formal yang lain. Pendidikan formal pada jenjang SD adalah salah satu jenjang pendidikan yang penting dalam upaya meningkatkan kualitas SDM yang unggul. Pada jenjang tingkatan SD inilah kemampuan dan keterampilan dasar anak digali dengan baik untuk bekal pendidikan lanjut maupun sebagai bekal untuk menghadapi masa yang akan datang. Hal tersebut sesuai dengan pendapat Tridhonanto (2015: 44) yang menjelaskan bahwa di Sekolah Dasar, anak diharapkan memperoleh dasardasar pengetahuan dan keterampilan yang dianggap penting untuk keberhasilan melanjutkan studi dan penyesuaian diri dalam kehidupannya kelak.

Anak-anak memiliki ciri khas dan perkembangan yang berbeda-beda. Secara umum dapatdibedakan beberapa aspek utama kepribadian individu anak menurut Piaget (Ibda: 2015) yaitu aspek (1) kognitif, (2) fisik- motorik, (3) sosio emosional, (4) bahasa, (5) moral, dan (6) aspek keagamaan. Piaget mengkategorikan fungsi- fungsi dan perilaku kognitif ke dalam tahapan utama yaitu periode sensori motorik $(0-2$ tahun), periode praoperasional (2-7 tahun), periode operasional konkrit (7-12 tahun) dan periode operasional formal (12-15 tahun). Berdasarkan tahapan tersebut, anak usia Sekolah Dasar berada pada tahap operasional konkrit, dimana anak akan mudah memahami materi atau pengetahuan apabila anak dihadapkan pada sesuatu atau kondisi yang nyata. Perilaku seorang wirausaha dibentuk melalui tiga faktor, yaitu bawaan sejak dia lahir, faktor lingkungan, serta faktor latihan (Wahyudin, 2012 :61), faktor latihan berwirausaha nantinya akan memberikan pengaruh yang lebih baik disbanding dengan kedua faktor lainnya yaitu bawaan sejak lahir dan lingkungan. Melalui adanya suatu pelatihan-pelatihan yang dilaksanakan oleh perilaku wirausaha dapat membentuk kemandirian psikologis dan juga sikap mental wirausaha. Salah satu cara menanamkan jiwa kewirausahaan pada siswa SD yaitu diadakannya kegiatan ekstrakulikuler. Kegiatan ekstrakurikuler ialah kegiatan pendidikan di luar jam sekolah peserta didik untuk membentuk pengembangan keterampilan peserta didik sesuai kebutuhan mereka baik potensi anak, bakat anak, dan minat anak melalui kegiatan yang secara khusus dilaksanakan di sekolah. Contohnya diadakanya kegiatan ekstrakulikuler kewirausahaan, di dalamnya siswa melakukan kegiatan jual beli misalnya di Koperasi Sekolah, siswa diajak untuk memerankan seorang kasir yang mengoperasikan komputer serta mencatat pengeluaran serta pemasukan Koperasi Sekolah dengan pengawasan dari guru yang mengampu ekstrakulikuler tersebut. Dari kegiatan tersebut diharapkan siswa memiliki bekal dalam berwirausaha dan mampu mengoperasikan komputer agar mampu mengikuti perkembangan aman yang mengharuskan generasi mendatang melek akan teknologi.

\section{Manfaat Penanaman Jiwa Kewirausahaan Pada Anak Usia SD}

Jiwa kewirausahaan memberikan kontribusi yang positif bagi perkembangan pola pikir anak. Kewirausahaan menuntut untuk bekerjasama satu sama lain, anak mampu untuk menjalin sebuah komunikasi yang baik dengan orang lain,menjadi pribadi kreatif dan berani mencoba dengan berbagai kegiatan-kegiatan seperti mengikuti kegiatan koperasi yang ada di sekolahnya. Kegiatan koperasi dapat memberikan esempatan kepada setiap anak untuk belajar berbisnis, sikap anak-anak berani menanggung resiko juga merupakan manfaat penanaman jiwa kewirausahaan pada anak usia SD. Tantangan-tantangan yang dihadapi anak dalam melaksanakan kegiatan kewirusahaan yang harus dijalani dan anak dapat mengambil hal yang sepantasnya baik untuk kegiatan usahanya tersebut. Tentu dalam hal ini banyak resiko yang harus ditanggungnya dan anak tidak akan takut dengan masalah seperti itu lagi. Selain itu penanaman jiwa kewirausahaan pada anak usia SD yaitu melatih siswa menghadapi hal-hal baru yang belum mereka temukan di lingkungan sekitarnya 
misalnya dalam mengoperasikan komputer sederhana yang mengharuskan generasi milenial dapat mengikuti perkembangan teknologi.

\section{SIMPULAN}

Berdasarkan pembahasan diatas disimpulkan bahwa menanamkan jiwa kewirausahaan pada anak usia SD sangat diperlukan karena dapat memberikan bekal dasar agar mampu menghadapi tantangan ekonomi dari era digital yang sudah mulai berkembang pada masa ini sampai di masa mendatang yang menuntut kemahiran dalam penggunaan teknologi. Penanaman jiwa kewirausahaan pada anak usia SD tersebut dapat dicontohkan melalui kegiatan ekstrakulikuler kewirausahaan yang di dalamnya siswa melakukan kegiatan jual beli misalnya di Koperasi Sekolah, siswa diajak untuk berperan sebagai kasir yang mampu mengoperasikan komputer serta mencatat pengeluaran serta pemasukan Koperasi Sekolah dengan pengawasan dari guru yang mengampu ekstrakulikuler tersebut. Dari kegiatan tersebut diharapkan siswa memiliki bekal dalam berwirausaha dan mampu mengoperasikan komputer agar mampu mengikuti perkembangan zaman yang mengharuskan generasi mendatang melek akan teknologi.

\section{DAFTAR PUSTAKA}

Afandi, R. (2013). Penanaman Jiwa Kewirausahaan Pada Siswa Sekolah Dasar. Jurnal Pemikiran dan Pengembangan SD. 1(2): 10-19.

Aditya dan Edy. (2012). Analisis Faktor-Faktor Motivasi Yang Mempengaruhi Minat Berwirausaha. 1(1), 130-137.

Daryanto dan Rahardjo. (2012). Model Pembelajaran Inovatif. Yogyakarta: Gava Media.

Ibda, F. (2015). Perkembangan Kognitif: Teori Jean Piaget. Jurnal Intelektualita. 1(1): 32-34.

Kasmir. (2011). Analisis Laporan Keuangan. Jakarta: Grafindo Persada.

Koran Jakarta. (2018). Jumlah Wirausaha Tembus 3,1 Persen. Diakses dari www.koran-jakarta,com/jumlah-wirausaha-tembus-3-1-persen/ pada 8 September 2019.

Pratomo, Y. (2019). APJII: Jumlah Pengguna Internet di Indonesia Tembus 171 Juta Jiwa. Diakses dari https://tekno-kompas.com/read/2019/05/16/03260037/apjiijumlah-pengguna-internet-di-indonesia-tembus-171-juta-jiwa pada tanggal 8 September 2019.

Saroni. (2013). Mendidik dan Melatih Entrepeneur Muda. Yogyakarta: Ar-Ruzz Media. Sugiyono. (2012). Metode Penelitian Kuantitatif Kualitatif dan R\&D. Bandung: Alfabeta. Tridhonanto, A. (2014). Mengembangkan Pola Asuh Demokratis. Jakarta: Gramedia.

Wahyudin, U. (2012). Pelatihan Kewirausahaan Berbasis Ekokultural untuk Pemberdayaan Masyarakat Miskin Pedesaan, Mimbar Jurnal Sosial dan Pembangunan UNISBA. 28 (1): 55-64. 